\title{
Model development of expert estimation of quality of transport interchange functioning
}

\author{
Margarita Panteleeva ${ }^{1, *}$, and Svetlana Borozdina ${ }^{1}$ \\ ${ }^{1}$ Moscow State University of Civil Engineering, Yaroslavskoe shosse, 26, Moscow, 129337, Russia
}

\begin{abstract}
This article is dedicated to the development of new and effective intellectual model of road junction for the modern urban space. Significant reserves lie in improving the organization of traffic. Effective traffic management in these conditions should ensure the loading of the transport network to the point of its capacity and maintain a continuous uniform movement, albeit at relatively low speeds. In addition, to meet the needs of the modern economy and society in reducing transport costs and increasing the speed of delivery of goods, transport companies have to use the means of modern technology, and modernize the organization of their business. This article is devoted to the formation of a knowledge-based system analysis, methods of mathematical modelling and simulation, the enlarged model for evaluating the performance of transport interchanges, which is supposed to solve the problem of high load of the road network, taking into account not only quantitative parameters, which characterize the system under consideration, but also the legal basis for the formation of relations between all subjects of the transport interchange.
\end{abstract}

\section{Introduction}

The level of technological quality of the transport highways, the quality of the legal regulation of the circulation of the relevant communications, as well as the management of various infrastructural facilities in this area are key factors in the successful development of the state economy. Therefore, ensuring the efficient and uninterrupted operation of infrastructure is a top priority for the country's authorities. However, how to achieve these conditions, and how to identify existing problems now? How to understand what transport infrastructure facilities can be built at various levels of communication between different subjects of legal relations in the state? All these issues are related to the process of assessing the quality of the functioning of transport nodes.

The efficiency of the transport system cannot be considered only within the framework of achieving optimal implementation of the relevant processes within the system. The main tasks of the transport system are to meet the needs of the economy in the transport of goods and ensure mobility of the population. In this regard, a certain balance between the contradictory requirements of the economy and society will always determine the effectiveness of the transport system. A striking example is the passenger's desire for the transport to come to a stop as soon as the passenger has approached it and the carrier's desire

*Corresponding author: anteikom@yandex.ru 
to establish such an interval of motion so that the vehicles are always full and bring the maximum income.

Thus, the requirements for transport infrastructure facilities should be established based on the potential level of demand for the use of its resources by citizens and organizations. Thus, the construction of new roads can be assessed taking into account the more intensive dynamics of their operation - due to the expected growth in the motorization of the population of the state, the construction of the airport - taking into account the possible use of its resources by international airlines, as a consequence - with increasing capacities of the relevant infrastructure facility.

\section{Materials and methods}

At present, the design of transport interchanges and individual congresses in Russia is regulated in particular by existing standards for road design [2], as well as some recommendations [3, 4]. However, in Russia there is still no guidance for setting and determining service levels (LOS - Level of Service) of transport facilities. The level of service shows the safety, comfort, freedom and speed of movement (travel time) of the driver on certain types of roads and highways.

Verification of the provision of bandwidth is increasingly carried out by simulation methods in a visual interactive form - this is a kind of mathematical modeling in which the description of the transport interchange model is given in the form of behavioral algorithms and interrelations of the elements of the modeled system $[5,6,7]$. The algorithms used make it possible to simulate both the behavior of the elements of the system and the entire system as a whole, and to determine the required parameters for the functioning of the system. However, other indicators of the functioning of the transport interchange, as systems, are estimated based on outdated domestic standards. Most often, expert methods with partial application of information technologies are used to evaluate the functioning of various transport highways.

\section{Results}

To optimize the functioning of the traffic intersection of a large city, with the existing road network, to provide the widest possible range of public transport services, such as increasing the capacity, providing the desired speed, comfortable, safe and informational conditions for the movement and delivery of goods, etc., the authors of this article suggest a technique for modeling the transport interchange based on statistical and expert data on the intensity of the traffic flow in the real urban area.

Each next stage of the proposed methodology (Figure 1) is a logical continuation of the previous all together they realize the synthesis of the structure of the projected transport interchange system. Steps 1-3, 5 are system tasks that consider the intensity of city traffic flows, the existing transport infrastructure as a single polygon for the creation of a transport interchange system. The fourth stage represents a set of particular problems that examine the functioning of the basic objects of the transport interchange system as independent entities.

In the framework of this study, the authors are studying the fourth stage of the proposed method "Determination of optimal technical and economic parameters of basic objects of the transport interchange system". To do this, the authors create an "Enlarged model of the process of expert evaluation of the quality of the traffic interchange", which consists of five logically interrelated blocks that characterize the main processes used to create a pilot project of the simulation model of the transport interchange. 
Step 1. Study transport and distribution complex city and determination of the most intense components

Step 2. Construction of a model of interacting adjacent transport service areas

Step 3. Determining the location geographically distributing components - base objects transport interchange system

\section{Stage 4. Determination of optimal technical and economic parameters of the} basic objects of the transport interchange system

Step 5. Determination of the most effective version of the structure of the transport interchange system

Fig. 1. Technique of synthesis of the structure of the transport interchange system.

\section{Discussion}

Figure 2 shows the author's model of the process of expert evaluation of the quality of the traffic interchange. To understand the logic of the expert evaluation process, it is necessary to consistently consider all five blocks of the proposed model. Each block [8] represents a separate sphere of application of the proposed author's model:

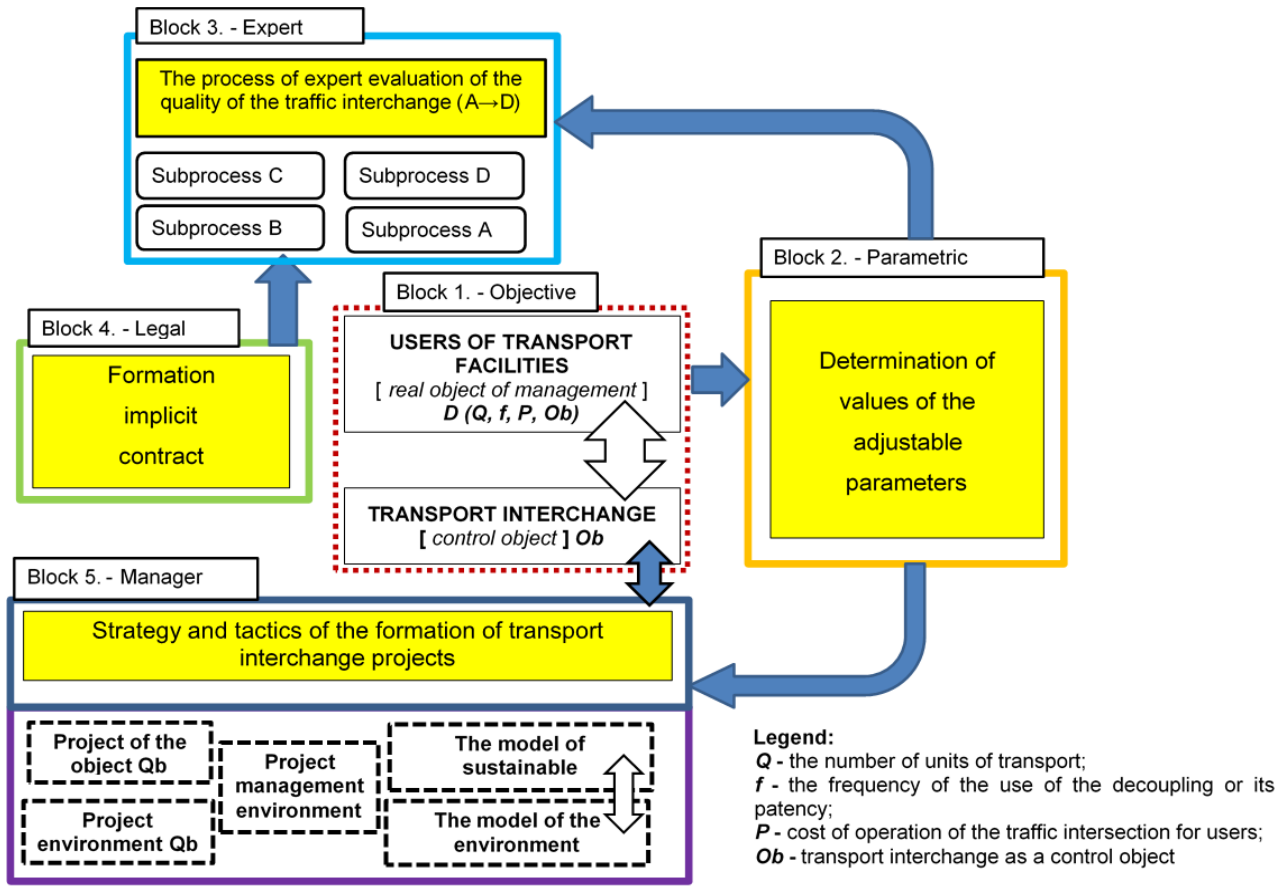

Fig. 2. Enlarged model of the process of expert evaluation of the quality of the traffic interchange. 
- Block 1. - Objective.

- Block 2. - Parametric.

- Block 3. - Expert.

- Block 4. - Legal.

- Block 5. - Manager.

Block 1 - "Objective". It consists of a control object [Ob], which is represented by a traffic intersection, and a real control object [D], which is represented by users of the traffic intersection. As users of the traffic interchange, the following cases were selected in the case under study: Q - the number of units of transport; $f$ is the frequency of use of the decoupling or its patency; $\mathrm{P}$ - cost of operation of the traffic intersection for users; $\mathrm{Ob}$ - transport interchange as a control object.

Block 2 - "Parametric". This block allows you to identify and determine the value of the adjustable parameters that affect the quality of the traffic intersection. All parameters are divided into two groups: technical and economic, and represent a means of separating and changing the composition of the regulated parameters. Technical parameters include automated and mechanized measurements:

1.1. Intensity of movement.

1.2. Composition of movement.

1.3. Distribution of cars on lanes.

1.4. Density of the transport stream.

1.5. The coefficient of loading the road by traffic.

1.6. And other parameters.

The economic parameters include the results of marketing research on the solvency of consumers [8]:

2.1. Field (primary).

2.2. Office (secondary).

Block 3 -"Expert". Within the framework of this block, the expert evaluation process $(A \rightarrow D)$ of the quality of the traffic interchange is presented. This process consists of four subprocesses:

- Subprocess A - Targeted formation of knowledge about the parameters of the functional environment of the transport interchange and the quality of its functioning.

- Subprocess B - consists of the formation of intermediate goals and the forecast of final states based on the adjustable parameters selected in the Block2.

- Subprocess C - Carry out a horizontal analysis to clarify the correspondence of goals and the actual functioning of the traffic intersection.

- Subprocess D - drawing up an expert opinion and forming a strategy for changing projects, tools for automatic and interactive formation of projects and design strategies, means for correcting simulation designs and design, means for identifying and changing the composition of control and adjustable parameters.

Block 4 - "Legal". Within the framework of this block, an implicit contract is being formed that monitors the institutional foundations of the transport interchange projects being created. Block 5 - "Manager". Allows you to create a strategy and tactics for the formation of transport interchange projects based on the isolation of macroelements of a qualitatively functioning system [9- 12].

\section{Conclusion}

The system approach to solving the problems of the transport interchange system today should be viewed as the implementation at the state level of a complex integrated policy 
based on the synthesis of transport management systems and urban planning, implemented through relevant sectoral legal frameworks, land use policies and urban traffic management $[14,15]$. Only such a synthesis of management becomes a necessary condition for eliminating the "transport collapse" in large cities, achieving a high level of quality of transport services, improving the quality of life of the population as a whole.

The basic principles of the integrated approach in transport policy at the official level were outlined in the "Transport Strategy of the Russian Federation for the Period to 2020" $[16,17]$ adopted in 2005 . The following main directions of development of transport systems can be singled out. There are:

1) reorientation of socio-economic assessment of the efficiency of transport systems from voluminous performance indicators to socially-oriented indicators related to meeting the needs of consumers;

2) the use in the management of transport systems of modern means of telematics, allowing in real time to obtain objective information about the operation of the control object and to develop optimal management decisions;

3) improving the technical means of transport in the direction of reducing operating costs and environmental pollution, increasing safety through the extensive use of intelligent control systems by both rolling stock and the transport system as a whole;

4) improvement of technological processes of transport systems in the direction of their interspecific integration and automation of storage, handling and movement of route vehicles.

However, one has to state that practically none of the principles of this strategy has been implemented for today, primarily because of the lack of appropriate legal, institutional, personnel and financial support. Moreover, with the adoption in November 2008 of the new "Transport Strategy of the Russian Federation for the period until 2030" [18, 19], the previously formulated clear principles ceased to exist as explicit, dissolved in the overall volume of the text of the new strategy, became blurred, implicitly identified in the articles of solutions to transport problems. The city is not represented in the plans of the new strategy as an independent transport-forming facility, which requires a special approach to solving the urgent problems [20]. It is especially worth noting that the implementation of a new strategy is impossible without the development of a methodology for planning, designing and systemic use of modern computer equipment, communications and software.

\section{References}

1. Ofitsial'nyy sayt Federal'noy sluzhby gosudarstvennoy statistiki (Rosstat, 2018) http://government.ru/department/250/events/

2. Russian Standard SNIP 2.05.02-85 (Gosstroy Rossii, Moskva, 2004)

3. Tekhnicheskie ukazaniya po proektirovaniyu peresecheniy i primykaniy avtomobil'nykh dorog (VSN 103-74) (Transport, Moskva, 1975)

4. I. Polyakova, E. Chibisova, Economy and entrepreneurship 5(70), 579-582 (2016)

5. M.S. Panteleeva, IOP Conf. Series: Earth and Environmental Science 90, 012119 (2017)

6. V.O. Chulkov, Infografija. Tom 4: Mnogourovnevoe infograficheskoe modelirovanie. Modul'ny jkurs lekcij (SvR-ARGUS, Moskva, 2007)

7. N.A. Bondareva, M.Ju. Mishlanova, G.A. Syzrancev, S.M. Gorkina, Monitoring rynka nedvizhimosti: metodologija, rezul'taty, zakonomernosti (MGSU, Moskva, 2011)

8. I. Polyakova, E. Vasilyeva, IOP (Earth and Environmental Science) 90, 012121 (2017)

9. Otraslevoy metodicheskiy dokument. Rekomendatsii po obespecheniyu bezopasnosti dvizheniya na avtomobil'nykh dorogakh (2011) 
10. Road and Transportation Research Association (FGSV), Guidelines for Integrated Network Planning (RIN) (2008)

11. Research Association for Road and Traffic Systems (FGSV), Handbook for the Suspension of Road Traffic Installations (2009)

12. Research Association for Roads and Transportation (FGSV), Working Group "Road Design": Guidelines for the Construction of Motorways (RAA) (2008)

13. Transportnaya strategiya Rossiyskoy Federatsii na period do 2020 g. (Mintrans RF, Moskva, 2005)

14. Transportnaya strategiya Rossiyskoy Federatsii na period do 2030 g. (Mintrans RF, Moskva, 2008)

15. An. Mottaeva, IOP (Earth and Environmental Science) 90, 12138 (2017)

16. E. Vasilyeva, T. Sazonova, IOP (Earth and Environmental Science) 90, 012116 (2017)

17. I. Polyakova, E. Vasilyeva, N. Vorontsova, IOP (Earth and Environmental Science) 90, 012136 (2017)

18. A.S. Misharin, O.V. Evseev, Gosudarstvo i transport, 2(45) (2013)

19. As. Mottaeva, MATEC Web of Conferences 106, 08072 (2017)

20. An. Mottaeva, IOP (Earth and Environmental Science) 90, 12117 (2017) 